\title{
THE INFLUENCE OF RADIATION ON HUMAN FERTILITY
}

\author{
L. MONDORF AND M. FABER \\ The Finsen Laboratory, Finseninstitutet og Radiumstationen, Copenhagen
}

(Received 2nd September 1967)

\begin{abstract}
Summary. The number of children born to 180 females exposed to abdominal fluoroscopy in connection with an attack of intussusception in infancy or childhood was compared to the number born to women who were treated for the same disease without fluoroscopy.

No difference was found between the number of children born or the age distribution of birth between the two groups. The significance in relation to the known radiation sensitivity of mice is discussed.

The sex ratio in this and a comparable series shows an unexpected though statistically non-significant increase in male births.
\end{abstract}

Peters \& Levy $(1963,1964 a, b)$ observed a decrease in fertility in infant mice irradiated with $20 \mathrm{r}$ at varying ages shortly after birth. This decrease was most marked at the age of 3 weeks and could be recognized both as a high incidence of total sterility and as a marked decrease in total reproductive capacity in the non-sterile mice. Irradiated mice killed when the reproductive capacity was exhausted had no remaining oocytes. If the irradiation was given at an earlier or a later age the effect was much less pronounced.

It appeared profitable to study whether the same effect could be demonstrated in humans irradiated during childhood.

The greatest problem was to find a group of women who had been exposed to a reasonably large gonadal dose in childhood during a disease preferably of short duration which would leave no residual defect that might, later in life, influence fertility. For this reason we have been reluctant to study patients with hip disorders where the gonadal exposure must be high, but where a residual lesion may influence fertility. We may, however, have over-estimated this reservation. Zachau-Christiansen (1967) finds 2.77 pregnancies per woman with previous hip disease which compares favourably with our $2 \cdot 3$.

An acceptable test population was found among children treated for intussusception by barium-enema under fluoroscopy control. This treatment was introduced in Denmark in 1927 (Nordentoft, 1943) and the children first exposed are now close to 50 years. We feel that these children after treatment must be considered normal and we have, during our interviews, found no symptoms indicating that these persons whether irradiated or not were different from the normal population. Thanks to Dr Jens Munk Nordentoft we were able to acquire a roster of close on 1000 children treated during the years 1927 to 1935 . Out of this group only 316 were female. We have so far been 
TABLE 1

KNOWN FEMALE CHILDREN

TREATED FOR INTUSSUSGEP-

TION BETWEEN 1927 AND 1935

All female cases on roster $\quad 316$

Visited

Dead

Moved abroad

Unmarried

Unco-operative

Unidentifiable

9

Total

TABLE 2

FERTILITY OF PATIENTS WITH INTUSSUSCEPTION

\begin{tabular}{|c|c|c|c|c|c|c|}
\hline & \multicolumn{2}{|c|}{$\begin{array}{l}\text { Intussusception before } \\
\text { the age of } 2 \text { years }\end{array}$} & \multicolumn{2}{|c|}{$\begin{array}{l}\text { Intussusception after } \\
\text { the age of } 2 \text { years }\end{array}$} & \multicolumn{2}{|c|}{ All } \\
\hline & Fluoroscopy & $\begin{array}{c}\text { No } \\
\text { fluoroscopy }\end{array}$ & Fluoroscopy & $\begin{array}{c}\text { No } \\
\text { fuoroscopy }\end{array}$ & Fluoroscopy & $\begin{array}{c}\mathcal{N o}_{0} \\
\text { fluoroscopy }\end{array}$ \\
\hline $\begin{array}{l}\text { No. of patients } \\
\text { No. of children } \\
\text { Mean age at }\end{array}$ & $\begin{array}{r}57 \\
128\end{array}$ & $\begin{array}{r}54 \\
131\end{array}$ & $\begin{array}{l}34 \\
88\end{array}$ & $\begin{array}{l}35 \\
77\end{array}$ & $\begin{array}{r}91 \\
216\end{array}$ & $\begin{array}{r}89 \\
208\end{array}$ \\
\hline $\begin{array}{l}\text { birth (years) } \\
\text { Child/patient } \\
\text { Abortus/patient }\end{array}$ & $\begin{array}{r}25 \cdot 9 \\
2 \cdot 2 \\
0 \cdot 2\end{array}$ & $\begin{array}{r}26 \cdot 1 \\
2 \cdot 4 \\
0 \cdot 4\end{array}$ & $\begin{array}{r}27.6 \\
2.6 \\
0.7\end{array}$ & $\begin{array}{r}26 \cdot 5 \\
2 \cdot 2 \\
0 \cdot 3\end{array}$ & $\begin{array}{r}26 \cdot 6 \\
2 \cdot 4 \\
0 \cdot 4\end{array}$ & $\begin{array}{r}26 \cdot 3 \\
2 \cdot 3 \\
0 \cdot 3\end{array}$ \\
\hline
\end{tabular}

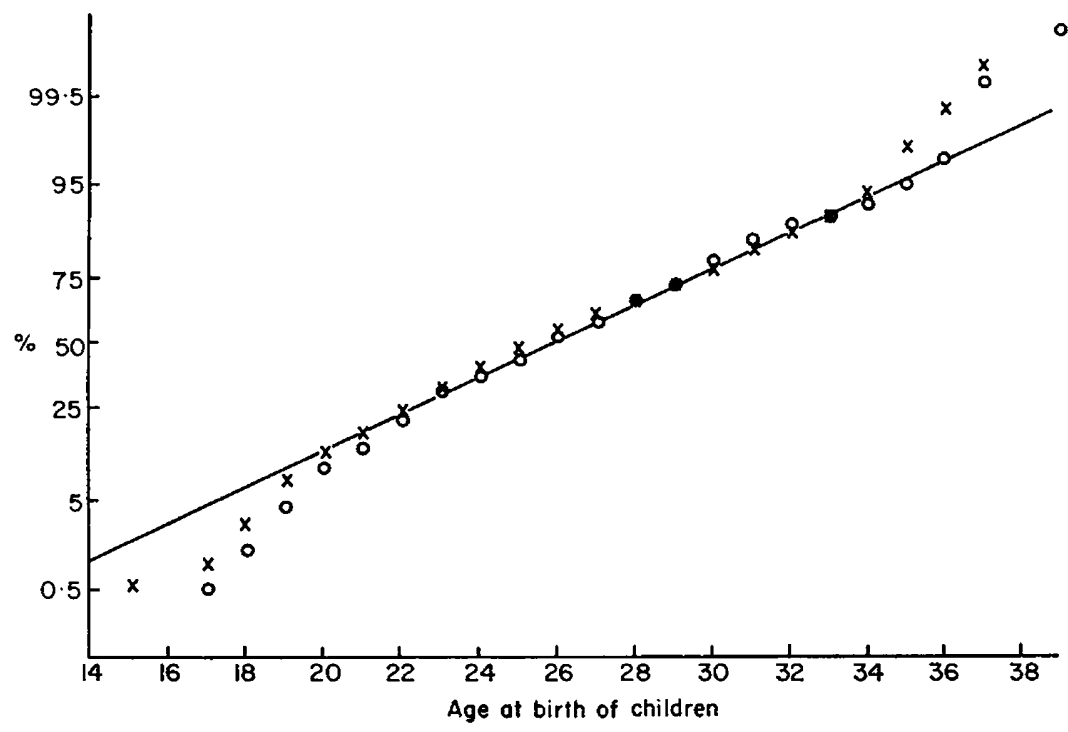

TEXT-FIG. 1. Distribution of age at birth or abortion of irradiated $(0)$ and non-irradiated $(x)$ mothers drawn on probability paper. 
able to trace the present address of 243 of these, but only 180 have been available for visit and interview, as can be seen in Table 1. The results of the interviews are listed in Table 2. The greatest difficulty has been the presence

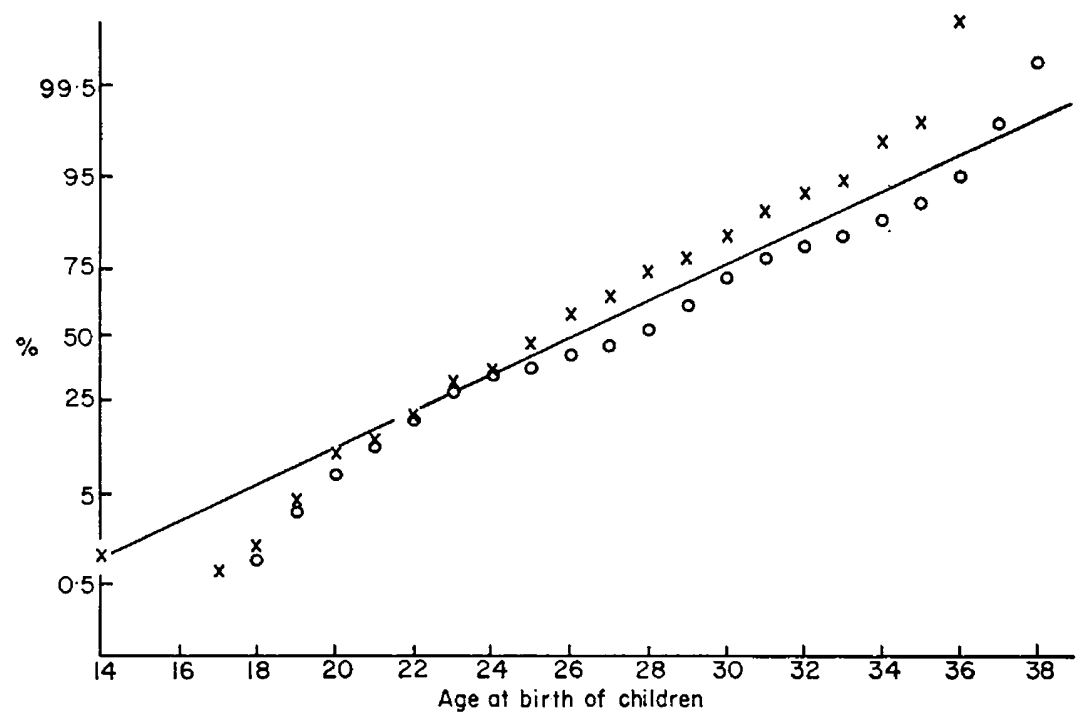

TEXT-FIG. 2. Distribution of age at birth or abortion of mothers irradiated before $(x)$ or after $(0)$ age 2 years drawn on probability paper.

of infants only registered by sex and a common family name without proper reference to name and address of parents. As control population we used the children with intussusception who were treated with surgical intervention, reposition with water-enema without fluoroscopic control or who showed spontaneous regression.

TABLE 3

\begin{tabular}{l|rr|cc}
\hline & \multicolumn{2}{|c|}{ Irradiated } & \multicolumn{2}{c}{ Non-irradiated } \\
\cline { 2 - 5 } \cline { 3 - 5 } & Males & Females & Males & Females \\
\hline Mondorf \& Faber & 117 & 93 & 95 & 104 \\
$\quad$ Intussusception & & & & \\
Zachau-Christiansen & 145 & 122 & & \\
Hip joint dislocation & 57 & 40 & & \\
Haemangioma & 319 & 255 & & \\
& & & & \\
\hline
\end{tabular}

From the table it appears that the number of children born to the irradiated and non-irradiated mothers is practically the same; if anything, the irradiated have a slightly higher fertility than the untreated mothers. The age at birth of first child, and the mean age at birth of all the children agree very closely in the two groups. It is, however, the number of children born late in life which is of greatest interest. Accordingly, the cumulative number of births in 
relation to the age of the mother has been calculated and presented on probability paper. It is quite evident that the four groups presented: those irradiated before the age of 2 years, those irradiated after the age of 2 years, all the irradiated and all the non-irradiated show the same distribution curve without any sign of a decrease in fertility late in life.

It is generally accepted (Neel, 1963) that gonadal irradiation of the mother will give rise to a shift in the sex ratio of the children with a preponderance of females, although no single experiment is statistically significant. In the present study, 210 children of irradiated mothers show an incidence of 0.443 female children while the incidence in the 208 children of non-irradiated mothers is 0.522 . This difference is not significant at the $5 \%$ level. The sex proportion of the non-irradiated shows a higher incidence of females than expected in the normal population. It is of interest that Zachau-Christiansen, in a group of females irradiated for hip diseases and for haemangiomas in the pelvic region, finds practically the same results (Table 3 ). When the combined results are compared to the sex proportion of Denmark as a whole the significance is still below $5 \%$.

We have made no attempt to measure the gonadal dose to which these children were exposed. However, by comparison with X-ray exposures where gonadal doses have been measured (Hammer-Jacobsen, 1963) we feel that the gonadal dose will be in the region from 1 to $5 \mathrm{r}$.

The negative result may be due to a number of factors.

First of all we do not know whether there is a period where the human ovary is sensitive to irradiation, and at what age such a period might occur. The fact that the 3-week-old mouse must be considered at pre-puberty can only give limited guidance. The number of human oocytes shows a rapid decrease from the 7th month of pregnancy to 6th month post partum and continues to decrease at a slower rate at least to the age of 7 years (Baker, 1963, 1966). A sensitive period could be expected at any time during this decrease.

A human population can never show the same pattern in fertility as the experimental mouse, when attempts are made to get as many litters as possible. In the population investigated, the number of children born to an irradiated or an untreated mother is $2 \cdot 3$. It was, however, felt that the number of ovulations potentially able to produce a child would be independent of the number of pregnancies and that the question would be whether radiation could reduce the number of oocytes to such an extent that sterility would appear late in the fertile period due to a lack of oocytes. With the radiation doses to which these children have been exposed and the time at which the irradiation took place such a destruction has not taken place. Clinical evidence which suggests a possibility for repair in man (Mole, 1959) may also complicate the interpretation.

Some indication of the doses necessary to induce sterility in man can be derived from Baker's (1963, 1966) finding that the ovary of pre-puberal monkeys appears to be resistant to doses as high as $4000 \mathrm{r}$. Unfortunately the monkeys had been killed a few days after the radiation, and no monkeys had been irradiated at an early age. Studies of Reifferscheid (1910) could, however, be cited as evidence that the monkey is more resistant to X-ray irradiation than are humans. 


\section{REFERENCES}

BAKER, T. G. (1963) A quantitative and cytological study of germ cells in human ovaries. Proc. $R$. Soc. Lond. B, 158, 417.

Baxer, T. G. (1966) The sensitivity of oocytes in post-natal rhesus monkeys to X-irradiation. 7 . Reprod. Fert. 12, 183.

Hammer-Jacobsen, E. (1963) Significant radiation dose in diagnostic radiology. Acta radiol. Suppl. 222.

Mole, R. H. (1959) Impairment of fertility by whole-body irradiation of female mice. Int. F. radiat. Biol. 2, 107.

NeEL, J. V. (1963) Changing perspectives on the genetic effects of radiation. Thomas. Springfield, Illinois.

Nordentoft, J. M. (1943) The value of the Barium-enema in the diagnosis and treatment of intussusception in children. Acta radiol. Suppl. 51.

Peters, H. \& Levy, E. (1963) Effect of irradiation in infancy on the fertility of female mice. Radiat. Res. 18, 412.

Peters, H. \& Levy, E. (1964a) Effect of irradiation in infancy on the mouse ovary. F. Reprod. Fert. $7,37$.

Peters, H. \& Levy, E. (1964b) Radiation sensitivity of the mouse ovary: Fertility and oocyte survival. Fert. Steril. 15, 407.

ReIfFerscheid, K. (1910) Histologische Untersuchungen über die Beeinflussung menschlicher und tierischer Ovarien durch Röntgenstrahlen. Z. Röntgen. 12, 233.

Zachau-Ghristiansen, B. (1967) Røntgenbestrålede kvinders afkom. Ugeskr. Laeg. 129, 279. 